\title{
Geography Student Teachers' Perceptions of Online Problem-based Learning Activities: A Case Study
}

\author{
Aubrey Golightly \\ Christo van der Westhuizen
}

\begin{abstract}
As online learning is being embraced in higher education, geography modules that implement problem-based learning can integrate online platforms to support geography curriculum delivery and facilitate student collaboration. The aim of this case study was to explore full-time BEd geography student teachers' $(n=98)$ perceptions of online problem-based learning activities in two third-year geography modules. The study used quantitative and qualitative research approaches based on questionnaire applications. The findings of the study indicate that the full-time BEd geography student teachers showed positive perceptions regarding the general aspects of online problem-based learning and the online problem-based learning process. Moreover, these student teachers were specifically impressed with the management of the university's learning management system (Sakai named Efundi), Google Docs, as a collaborative online space on which to compile the problem-based learning report. The student teachers also held positive perceptions of the role-players in online problem-based learning, as well as the assessment rubric used to assess the online problem-based learning activities; hence, these have good correlations with online community of inquiry principles.
\end{abstract}

Keywords: Geography education, teacher training, technology, active learning, online problem-based learning, community of inquiry. 


\section{Introduction and Problem Statement}

Universities and institutions of higher education are increasingly implementing online technologies in instructional environments to enhance teaching and learning experiences. The benefits of using online technologies to enhance learning in higher education are well documented (cf. Hamid et al. 2015; Lee 2014). As a result, the number of higher education students enrolling in online courses continues to grow. Most of these online courses are being developed within a learning management system (LMS) software application (Morueta et al. 2016). Within this LMS context and platform, collaborative tools, for example discussion forums and wikis, allow high levels of student-to-student and student-to-instructor interaction, which support teaching and learning models suitable for higher education. Moreover, research (e.g. De Wever et al. 2010) has shown that asynchronous online discussion is an ideal tool for supporting knowledge construction because students can cooperate and communicate with their peers, share knowledge and solve problems, all of which catalyse high-level thinking.

While online education provides many opportunities to interact and learn across distance and time, many students, according to Rapchack (2017), feel isolated when learning online on their own, and they miss personal interaction with their peers. According to the Community of Inquiry (CoI) model (Garrison, Anderson \& Archer 2000), an enriching online educational experience in a collaborative learning environment requires three interdependent elements, namely social presence, teaching presence and cognitive presence. This model has been well studied and researched in the literature and proves to be a meaningful framework for online course development and assessment (Rapchack 2017).

The rapid growth of online learning has led to the introduction of online PBL (Ellaway et al. 2015). Traditionally, PBL is usually conducted in classrooms, involving in-person, face-to-face interaction. As online learning is embraced in higher education, the development of online technologies can be used to supplement, or even replace, face-to-face PBL (Ryan et al. 2009). The Internet also allows for a different kind of class experience that does not require students ever to meet one another in person. Xie and Kim (2012) advocate the use of wikis for PBL.

With reference to geography and geography teacher training in a South African context, it is clear that relatively little research has been published on 
PBL or online PBL in pre-service teacher training settings. However, Dean (1999) argues that PBL offers lecturers an important vehicle whereby student teachers can be exposed to situations they are likely to face as professional educators. Additionally, Veldman et al. (2008) also clearly state that very few teaching and learning strategies can achieve the quality of learning in a South African context that is attained when using PBL. They are of the opinion that PBL satisfies all the requirements to help achieve the general aims that are prescribed by the South African Government (South Africa 2011).

\section{Conceptual and Theoretical Framework}

The education system in South Africa emphasises learner-centred education (South Africa 2011), which is based on the constructivist approach to teaching and learning. In constructivist learning approaches, the teacher no longer directs and feeds information to the learners, but guides the learners in discovering information, solving problems, constructing their own learning and understanding their own thinking processes (Aldridge et al. 2004). For the purpose of this study, the focus is on social constructivism. Social constructivism functions on the premise that the construction of individual meaning always occurs within the social context. Social constructivism emphasises the role of language, dialogue and shared understanding during teaching and learning. Social constructivism emphasises the acquisition of knowledge through interaction with the environment, instead of the teacher (Aldridge et al. 2004). Gergen (1995:21) points out that, within the social constructivist learning environment, the teacher facilitates the interaction between the student and the environment in the student's knowledge construction processes that are embedded in a particular context. Social constructivist teaching and learning strategies, such as PBL, inquiry-based learning and cooperative learning, encourage students to use active methods to create knowledge, based on prior knowledge, and reflect on their learning within a social environment (Ruey 2010; Schreiber \& Valle 2013). When students are being trained to become teachers, these teaching and learning principles should be embraced and practised (in lectures) also to adhere to higher cognitive levels (according to Bloom's taxonomy), as prescribed for higher education.

From the South African literature, it is clear that learner-centred instru- 
ction has not been taking place in most geography classrooms and that geography teachers have been experiencing challenges in the implementation of learner-centred instructional strategies in the geography curriculum. These challenges include large numbers of learners per class, the deprivation of facilities (such as libraries, internet access and computers), language barriers of geography learners and conceptual and pedagogical difficulties that geography teachers experience with the effective implementation of learnercentred instruction in their classrooms (Alexander et al. 2010; Muduane 2016; Wilmot \& Dube 2015). With reference to the last-mentioned challenge, it is necessary when training geography teachers, to introduce them to and involve them in learner-centred instructional strategies as well as online learning during their training. In this study, it was decided to involve the geography student teachers to PBL as a learning strategy, as Malan et al. (2014) state that PBL brings about the transformation from being a passive learner to being an active problem-solver. PBL can also assist student teachers in this instructional practice transformation. In their study, Park and Ertmer (2008) found that preservice teachers in the PBL group have changed their intended practices in teaching, learning and technology toward a more learner-centred instruction than those who were in the control group. In the following section, the focus is on PBL as an example of a social constructivist teaching and learning strategy.

\section{Problem-based Learning and Geography Education}

PBL focuses on students investigating real-world problems, rather than being directly instructed by lecturers. During the past few years, various geography educators from different countries have implemented PBL in geography and geography education (e.g. Caesar et al. 2016; Golightly 2018; Golightly \& Guglielmino 2015; Golightly \& Muniz 2013; Kwan 2008). It is also necessary to point out that the 2016 International Charter on Geography Education strongly recommended that geography educators should be supported by research that reflects on PBL in geography education (Kolossov, Van der Schee \& Lidstone 2016).

\section{PBL Models}

In the literature, many variations of PBL models are practised in educational settings around the world. For the purpose of this study, we only refer to 'pure' 
and 'integrated' PBL. In the pure PBL model, PBL is the main teaching and learning strategy implemented throughout the entire curriculum (Savin-Baden 2007), while in an integrated PBL model, PBL is integrated into a traditional teaching curriculum for a period of time (Kivela \& Kivela 2005). For the purpose of this study, an integrated online PBL format is followed.

\section{The PBL Process}

The PBL process is anchored by an ill-structured, real-world geography problem that has more than one solution, which is presented first. The students may be organised into small tutorial groups in which the students function as members of a team (Chernobilsky et al. 2005; Dolmans et al. 2001). The students begin to work on the problem and conceptualise their problem into more specific learning issues or objectives. These learning objectives are conceptualised into different learning tasks, and the team members have to do research in their own time and explore various kinds of information, using library resources, textbooks, internet articles and field studies. The students share and work with new information on the problem together (Lam 2009). After the students have discussed and analysed the problem, they gather and apply their knowledge to solve the problem by presenting multiple solutions to it (Tick 2007).

Recently, some studies on the implementation of PBL in online learning environments have been published (e.g. Duncan 2009; Günbatar \& Çavuş 2011; Gürsul \& Keser 2009; Sulaiman, 2011; Tsai \& Chiang 2013). In the online PBL environment, all meetings take place electronically, using the telephone, text-based chat or audio or video conferencing, or asynchronously, using discussion forums or email. The production of reports or presentations on their approach and solution is a common element of PBL activities. Tools such as wikis or Google Docs offer ways for students in different locations to create reports and presentations collaboratively on the same document (Glover 2014). One useful feature is the ability to add comments and automatically include a timestamp and the commenter's name (Ó Broin \& Raftery 2011). Tutors or facilitators can be included as observers in each group and thus track the development of the work. The box at the bottom right-hand side shows when another person is editing the document at the same time (Google Docs enables up to ten multiple users to collaborate simultaneously). The revision history is a very useful feature. It archives each saved version, which can be 
easily reviewed and allows for comparisons between versions. Note that the changes made to the document are highlighted and colour-coded to indicate who has made the changes (Reynolds 2016).

During the online PBL process, the online tutor provides appropriate scaffolds to students, assesses the group's progress and monitors the contribution of each group member to the group's work (Schmidt et al. 2009). It might be that online PBL requires more of a silent presence by the online tutor, along with appropriate hinting and prompting. The loss of nonverbal signals, such as eye contact, facial expressions and so forth, in online PBL, may have presented a decrease in communicative power, making it harder for tutors to give input in online PBL (Strømsø et al. 2004). However, various studies (e.g. Günbatar \& Çavuş 2011; Gürsul \& Keser 2009) report that students hold positive perceptions and attitudes towards the problem-based online learning environment. The study by Gürsul and Keser (2009) states that a PBL approach is more effective than traditional teaching methods concerning a variety of learning outcomes, and it brings about similar positive results when it is applied in online and face-to-face environments. Some of the reasons for this, according to Hazwanie et al. (2017), are that online technologies now enable PBL to be conducted anywhere, on any compatible device and at any time. In their studies, Dennis (2003) and Tichon (2002) found no significant difference in learning experience between face-to-face PBL and PBL in an online environment, regardless of learner styles, gender and group dynamics. Against this background, the main purpose of this case study is to explore the perceptions of geography student teachers of the implementation of online PBL in geography education.

\section{Research Objectives}

The research objectives that guided the study were:

- to explore the implementation of online PBL experiences in two different geography education modules in a BEd programme;

- to report on how geography student teachers perceive the online PBL experiences in the third-year geography modules; and

- to determine if the online PBL design of the two geography models is according to the CoI principles as perceived by the geography student teachers. 


\section{Research Methodology}

In this explorative case study approach, geography student teachers' perceptions of online PBL are researched. This approach involved the collection and analysis of quantitative and qualitative data (cf. Creswell 2009). This study has been conducted within the post-positivist paradigm. According to De Vos et al. (2012), post-positivism is based on the assumption that reality does not exist within a vacuum, but is dependent on and influenced by contextual and situational factors. Post-positivist approaches accommodate different methodological approaches and may include quantitative and qualitative research methods (Glicken 2003).

\section{Participants}

The participants in this study comprised all the full-time undergraduate BEd geography students of two third-year modules of consecutive years of a university in South Africa who have completed the online PBL questionnaire at the end of the six-week PBL intervention each year. The total $\mathrm{N}=98(\mathrm{n}=$ 56 in 2017 and $n=42$ in 2018). The 2017 student participants only needed to complete the CoI questionnaire $(n=53)$ to confirm that the online PBL activities are according to collaborative online learning environment principles.

\section{Quantitative Data}

In this case study, the one-shot experimental case study design (Leedy \& Ormrod 2001:235) consisted of making an observation in measuring the geography student teachers' perceptions and experience of the implementation of online PBL in the two third-year geography modules in a BEd programme.

\section{Data Collection and Analysis}

The quantitative data from two questionnaires were collected and analysed as follows:

(1) Using an adapted online PBL questionnaire of Golightly and Muniz (2013) after the implementation of the online PBL activities (see Table 2). The 
online PBL questionnaire is a 36-item, five-point Likert scale instrument that measures students' perceptions of the online PBL experiences. The online PBL questionnaire asks respondents to rate how important or relevant to their current learning they perceive each item to be. The students were asked to rate each item on a five-item scale $(1=$ almost never true of me; $2=$ not often true of me; $3=$ sometimes true of me; $4=$ usually true of me; or $5=$ almost always true of me). The online PBL questionnaire is divided into the following sections: general aspects of online PBL (ten items), online technology (seven items), process of online PBL (six items), and role-players (11 items).

The data analysis includes the following: the Cronbach alpha coefficient ( $\alpha$ values) for the sections in Table 1 varied between 0.73 and 0.84 . All the sections have $\alpha$ values of $\geq 0.7$ and can be included for analysis and interpretation. The reliability of the online PBL questionnaire is as follows: general aspects of online PBL $(\alpha=0.74)$, online technology ( $\alpha=78)$, process of online PBL $(\alpha=0.73)$ and different role-players, which include the online tutor $(\alpha=0.76)$, the online leader $(\alpha=0.84)$ and the online group members $(\alpha$ $=0.75)$.

Descriptive statistical techniques, such as the mean and standard deviation for the subsections of the online PBL questionnaire, were applied to organise, analyse and interpret the quantitative data.

(2) Community of inquiry (CoI) was measured with the modified CoI instrument, consisting of social presence, cognitive presence and teaching presence (Arbaugh et al. 2008). The five-point Likert scale of the CoI questionnaire, which contains 34 items, was adapted to fit the research context, where $1=$ 'strongly disagree' and $5=$ 'strongly agree'. The overall reliability of the CoI scale was greater than 0.90 , and the Cronbach alpha values for the teaching, social and cognitive presences were $0.94,0.91$ and 0.95 , respectively, suggesting high internal consistency of the CoI scale. Descriptive statistics were used to examine the participants' responses to the three elements: teaching presence (items 1 to 13), social presence (items 14 to 22) and cognitive presence (items 23 to 34 ).

The items were used as closely relevant to the current study, so we could accurately measure the participants' perceptions of problem-based learning. For social presence, an example item was 'I felt comfortable conversing through the online medium'. An example item for cognitive presence was 'The topics stimulated my interest in the course', and for teaching 
presence, an example item was 'The instructor provided clear instructions on how to participate in course learning activities'. In this study, item reliability was evaluated as $\alpha=0.82$ for social presence, $\alpha=0.90$ cognitive presence and $\alpha=0.94$ teaching presence.

\section{Qualitative Data Gathering and Analysis}

In the online PBL questionnaire, four open-ended questions were included at the end of the questionnaire. The open-ended questions focused on student teachers' perceptions on how the online PBL process could be improved, which online PBL activities they found meaningful, how well the group members worked together online and what could be done to improve the use of eFundi and Google Docs in the online PBL. The participants were also encouraged to elaborate in detail on these questions. The qualitative analysis began with coding the data, dividing the texts into small units (phrases, sentences and paragraphs) and assigning a label to each unit (cf. Creswell \& Plano Clark 2007). The qualitative data received enriched the quantitative findings and contributed to a deeper understanding and clarity of the phenomena found.

\section{Ethical Considerations}

This study took place within the PBL subproject as part of the Self-Directed Learning (SDL) Project at the North-West University. The SDL project was approved by the Ethics Committee of the university and complied with all the ethical regulations of the university. The participants provided written consent that the information supplied by them could be used in this study.

\section{Case Study Context}

The geography student teachers had six weeks (three weeks per online PBL activity) to formulate solutions to the stated problems. During this period, the students had to work on Google Docs on eFundi. Furthermore, the preparation of the geography education students included an orientation session in the form of a two-hour workshop, which included the presentation relating to the process of PBL, online technologies and role expectations of the students and web tutors in online PBL, as well as notes and articles that include readings on 
effective group processes, and websites discussing PBL. The students had the opportunity to ask questions regarding the PBL procedures. Prior to the initiation of the PBL activity in the classroom, the students were divided into groups. An online group consisted of four to six members. One of the group members acted as the online group leader. In the online PBL environment, the geography lecturers acted as online tutors for the different online groups. The online group members had to compile the online PBL report on Google Docs, which is embedded in the LMS of the university.

The BEd geography modules in the third year, as indicated in Table 1, were selected for the implementation of the six-week (three weeks per module) integrated online PBL experiences per year. The facilitators developed geography problems that were aligned with one of the module outcomes for each module during the three years. The third-year geography student teachers had to complete the integrated online PBL activities on Google Docs in eFundi. The online PBL groups worked collaboratively in eFundi, the LMS of the university, to complete the PBL activities on Google Docs. The geography lecturers responsible for the two third-year geography modules acted as online tutors during the six-week online PBL experiences.

Table 1: Third-year online geography problems

\begin{tabular}{|l|l|l|}
\hline $\begin{array}{l}\text { Third } \\
\text { year }\end{array}$ & $\begin{array}{l}\text { GEOE311 Population } \\
\text { Geography and Urban } \\
\text { Geography } \\
\text { Theme: Poor health in low- }\end{array}$ & $\begin{array}{l}\text { GEOE321 Climatology and } \\
\text { Geomorphology } \\
\text { Theme: Climate change in } \\
\text { income urban areas } \\
\text { South Africa } \\
\text { As beginner geography } \\
\text { teachers in a school situated } \\
\text { in a low-income informal } \\
\text { settlement in Ikageng, } \\
\text { Potchefstroom, you become } \\
\text { aware that the geography } \\
\text { learners in your class are } \\
\text { absent on a regular basis. In } \\
\text { discussions with the principal, } \\
\text { teachers, as well as the clinic } \\
\text { serious problem world-wide and, } \\
\text { according to scientists, this } \\
\text { threatens the future existence of } \\
\text { man on earth. In South Africa } \\
\text { there is great concern about the } \\
\text { impact that climate change } \\
\text { (global warming) will have on } \\
\text { our country's people and } \\
\text { environment. }\end{array}$ \\
\hline
\end{tabular}




\begin{tabular}{|l|l|l|}
\hline $\begin{array}{l}\text { sisters at the nearby medical } \\
\text { clinic, the poor health } \\
\text { conditions in the low-income } \\
\text { dwelling areas are highlighted } \\
\text { as the main reason. The } \\
\text { government body of the } \\
\text { school asks you to provide } \\
\text { possible solutions to the poor } \\
\text { health problems of learners } \\
\text { and residents in the area. }\end{array}$ & $\begin{array}{l}\text { The Department of Agriculture } \\
\text { Conservation and Environmental } \\
\text { the geography students with re- } \\
\text { ference to the presence of cli- } \\
\text { mate change in South Africa, as } \\
\text { well as possible measures which } \\
\text { the SA government could imple- } \\
\text { ment to, firstly, help manage this } \\
\text { problem and, secondly, to } \\
\text { combat it drastically. The } \\
\text { Department also wishes to know } \\
\text { what can be done by individuals } \\
\text { and households to make a } \\
\text { meaningful contribution. }\end{array}$ \\
\hline
\end{tabular}

\section{Results and Results Interpretation}

The findings and discussions of the perceptions, experience and evaluation of the geography student teachers will be discussed under the following themes: 'Evaluation of the CoI elements of the online PBL environment'; 'General aspects of online PBL'; 'Online technology'; 'The online PBL process'; and 'The different role-players in online PBL environment'. After that, the differences in perceptions and experience between male and female student teachers will be discussed.

\section{Evaluation of the CoI elements of the online PBL environment}

Table 2 presents the guideline mean scores, according to Arbaugh et al. (2008), for the evaluation of the three elements of the CoI framework regarding the students' experience of an online collaborative learning environment. The three interdependent elements are teaching presence, social presence and cognitive presence, which should be around 4.18, 3.98 and 4.14, respectively, to be deemed as an acceptable and effective online collaborative learning environment. 
Table 2: Summary of the evaluated scores of the three presences of the CoI framework evaluation, as perceived by the third-year geography student teachers

\begin{tabular}{|l|c|c|c|}
\hline Presences & $\begin{array}{c}\text { Mean } \\
\text { suggested score }\end{array}$ & $\begin{array}{c}\text { Mean } \\
\text { online PBL }\end{array}$ & \% Difference \\
\hline Teaching & 4.18 & 4.27 & $+1.8 \%$ \\
\hline Social & 3.98 & 4.13 & $+3.0 \%$ \\
\hline Cognitive & 4.14 & 4.16 & $+0.4 \%$ \\
\hline
\end{tabular}

(Van der Westhuizen 2017, adapted from Arbaugh et al. 2008)

From Table 2 it is evident that the online PBL activity of these two geography modules not only complies with the recommended average scores for online collaborative activities as perceived by the students, but is even slightly better, with 4.27 for the teaching presence, 4.13 for the social presence and 4.16 for the cognitive presence (Van der Westhuizen 2017). As PBL is seen as a higherorder learning activity (according to Bloom's taxonomy as reference), this evaluation correlates with findings of Morueta et al. (2016) that to perform higher-order tasks online, a strong teaching presence is necessary, which entails continuous guidance, structure and support to students. It is the responsibility of the instructor to design, scaffold, model and coach properly before and during the online activity. Regarding the social presence, the frequency of involvement by the group members will increase as the level of the task (according to Bloom's taxonomy) increases. Richardson and Ice (2010) found that a discussion based on real cases can stimulate more critical thinking than other types of tasks, such as a theoretical study or debate. Case studies showed a remarkable creative component because students had to build solutions to the real problem raised. Therefore, the degree of complexity and the nature of the task seem to condition the level of group cognitive activity. For complex activities, it is necessary to ensure a good social presence to achieve a high cognitive presence (Morueta et al. 2016). It can, therefore, be safely argued the online PBL activities, in this instance, adhere to good online collaborative learning environment principles. 


\section{General Aspects of Online PBL}

Table 3 represents the mean scores of the respondents' perceptions of general aspects of the online PBL experience. The highest scoring items in Table 3 indicated by respondents include 'The use of online PBL in the Geography module was meaningful' (mean = 4.33) and 'With time, however, I became more positive about my involvement with the online PBL activity' (mean = 4.28) and 'Online PBL motivated me to learn' (mean = 4.02). These results were confirmed with responses from the open-ended questions: 'It was very meaningful because it was thought provoking' (Respondent 34, male) and '...to see other students' opinions of different questions extended my own knowledge' (Respondent 8, female). This is most encouraging, as the implementation of a PBL experience shifts most of the responsibility of learning to the student. These findings correlate with other studies where online PBL was implemented, and students held positive perceptions of online PBL experiences (Duncan 2009; Ng et al. 2013). This can best be summarised by the following quote:

The fact that we had to do research ourselves, furthermore, you have worked with three other group members, thus you also had to read through their work first to ensure that you don't repeat something and that the work follows a logical sequence. My knowledge about the work improved very much, more so as it would have in contact sessions (Respondent 91, female).

Interestingly, although on average the respondents indicated that they accepted responsibility for their own learning, the following items rate as the lowest mean averages in the section: 'I prefer online PBL to the traditional lecturebased teaching strategy' (mean $=3.56)$ and 'I feel that I can learn online even when I am not being taught by the lecturer' (mean = 3.32). This lower mean scores indicate that, on average, the respondents still expect their lecturers to explain subject content, identify learning material for them, assess achievement of the learning outcomes and make decisions on their behalf. Another reason for the lower mean scores, as highlighted by Woods (1994), can be that in PBL, it is assumed that students have the necessary skills for problem solving, and this skill takes time to develop, which again may lead to the distrust some students have of online PBL.

These results indicate that online PBL can be effective in enhancing 
the student learning experience, but on initial presentation, online PBL may need to be implemented carefully to avoid student anxiety and ensure active participation in online tasks (Duncan 2009). These results also concur with a number of studies on PBL and enquiry-based learning (Nelson 2007) which reported that some students experiencing difficulties in engaging with studentcentred learning because it has been the student's first experience of this form of delivery.

\section{Table 3: Geography student teachers' perceptions of general aspects of online PBL experience}

\begin{tabular}{|l|c|}
\hline General aspects of online PBL experience & Mean \\
\hline The use of online PBL in the geography module was meaningful & $\mathbf{4 . 3 3}$ \\
\hline $\begin{array}{l}\text { With time, however, I became more positive about my involvement } \\
\text { with the online PBL activities }\end{array}$ & $\mathbf{4 . 2 8}$ \\
\hline $\begin{array}{l}\text { I acquired new knowledge through completion of the online PBL } \\
\text { activity }\end{array}$ & $\mathbf{4 . 2 7}$ \\
\hline $\begin{array}{l}\text { Online PBL as teaching/learning strategy should definitely be } \\
\text { integrated with all the full-time geography modules }\end{array}$ & $\mathbf{4 . 0 5}$ \\
\hline Online PBL motivated me to learn & $\mathbf{4 . 0 2}$ \\
\hline I enjoyed the online PBL activity in the geography module & $\mathbf{3 . 9 8}$ \\
\hline I see problems as challenges & $\mathbf{3 . 9 6}$ \\
\hline $\begin{array}{l}\text { I prefer online PBL to the traditional lecture-based teaching strategy } \\
\text { in Geography }\end{array}$ & $\mathbf{3 . 5 6}$ \\
\hline $\begin{array}{l}\text { I feel that I can learn online even when I am not being taught by the } \\
\text { lecturer }\end{array}$ & $\mathbf{3 . 3 2}$ \\
\hline $\begin{array}{l}\text { Initially I was negative about my involvement with the online PBL } \\
\text { activity }\end{array}$ & $\mathbf{2 . 8 9}$ \\
\hline
\end{tabular}




\section{Geography Student Teachers' Perceptions of Technology in Online Problem-based Learning}

Table 4 summarises the mean scores of the geography students' perceptions of the technologies and tools used for the online PBL activities. All the items in this section received high ratings, and with an average mean of 4.24 for the seven items, the students seemed fairly satisfied with the technological support for the online PBL activity. Furthermore, from these results it is clear that the geography student teachers acknowledged that the online environment for the PBL activities added flexibility to their learning, allowing more effective collaborative learning where all the group members could give meaningful input, compared to traditional forms of face-to-face collaboration. This was also strongly supported by the students in the open-ended questions, for example 'that all group members could work on different times and places contributed to friendly collaboration' (Respondent 16, female), 'that we could see how other members work with us' (Respondent 2, female), 'it was very comfortable, because we did not have to struggle to get all the group members together, with this method everybody has to contribute' (Respondent 42, female) 'it all contributed to a quality report which included everybody's point of view' (Respondent 5, male) and 'we could see exactly who did what' (Respondent 14, male). As the students had to work simultaneously in groups on their PBL reports on the Google Docs application, this explains why they found the application very effective (mean $=4.33$ ) to execute the PBL activity and to collaborate online (mean $=4.28)$ - 'the fact that we could work together from a distance and could nicely integrate everything' (Respondent 77, female) and 'I could ask group members online if my contribution was correct and could get feedback while working' (Respondent 81, female). Thus, Google Docs aided their collaborative learning, which confirms the satisfying evaluation of the social presence, which is 3\% higher (see Table 2) than the norm for online activities. Google Docs and the LMS were also fairly accessible throughout (mean of 4.28), and no major technical issues were reported. The findings from the study by Suwantarathip and Wichadee (2014) confirm that Google Docs play an important role in student learning. Google Docs is a tool that supports students to help one another in learning without restriction of time and place.

The findings of this section of the study further concur with the results of Sulaiman (2011) and Duncan (2009), who both reported that students' 
acceptance and perceptions of PBL and online learning were positive and encouraging; this despite encountering some technical issues during the intervention. Moving PBL online can provide scaffolding to support collaborative knowledge construction further (Chernobilsky et al. 2005)

Table 4: Geography student teachers' perceptions of online technology in PBL

\begin{tabular}{|l|c|}
\hline Online technology & Mean \\
\hline $\begin{array}{l}\text { Google Docs was very effective in the execution of the online } \\
\text { PBL activity }\end{array}$ & $\mathbf{4 . 3 3}$ \\
\hline eFundi and Google Docs were accessible at all times & $\mathbf{4 . 2 8}$ \\
\hline $\begin{array}{l}\text { The use of Google Docs supported collaborative learning } \\
\text { (group work) well }\end{array}$ & $\mathbf{4 . 2 8}$ \\
\hline $\begin{array}{l}\text { The online technology (eFundi) supported the online PBL } \\
\text { process in particular well }\end{array}$ & $\mathbf{4 . 2 7}$ \\
\hline $\begin{array}{l}\text { There were not many technical problems during the completion } \\
\text { of the online PBL activity on the wiki tool (Google Docs) }\end{array}$ & $\mathbf{4 . 2 6}$ \\
\hline $\begin{array}{l}\text { The use of online technology can effectively promote teaching } \\
\text { and learning in geography }\end{array}$ & $\mathbf{4 . 2 3}$ \\
\hline $\begin{array}{l}\text { The use of eFundi tools made the online PBL activity process } \\
\text { easier }\end{array}$ & $\mathbf{4 . 0 4}$ \\
\hline
\end{tabular}

\section{Geography Students' Perceptions and Experience of the Online PBL Process}

Table 5 portrays the means of the student teachers' perceptions of the online PBL process. From Table 5, it is comforting to see that one of the key skills to solving the stated problems successfully, namely to be able to integrate different sources, was also possible online and received a high mean score of 4.41. Furthermore, most of the respondents were of the opinion that their 
involvement in online PBL supported their taking responsibility for their own learning (mean $=4.22$ ). These results concur with Duncan's (2009) findings, where the students felt that the use of online PBL within the module allowed them greater autonomy and enabled them to engage with a wider range of literature and to develop greater engagement in the learning process in comparison to traditional lecture-led teaching. The researchers agree with Zhu (2012) that, through online, collaborative written reports, group discussions, debates and critiques of arguments, students can enhance knowledge construction through online PBL.

Surprisingly, the respondents also stated that the formulation of learning objectives was not difficult (mean $=4.21$ ). This differs from findings of Golightly and Muniz (2013), who reported in their study that students experienced difficulties in the formulation of learning objectives in order to solve problems. It is important to highlight that the researchers of this study, who acted as online tutors, gave the necessary guidance and support to students regarding the formulation of objectives in the initial training of the online PBL process, as well as throughout this part of the activity. Interestingly, against the findings of the above-mentioned authors, the respondents pointed out that they found it, to the contrary, not easy to do research about the set learning objectives.

\section{Table 5: Geography student teachers' perceptions of the online PBL process}

\begin{tabular}{|l|c|}
\hline Process of online PBL & Mean \\
\hline $\begin{array}{l}\text { Online PBL enables you to integrate different sources to solve the } \\
\text { problem }\end{array}$ & $\mathbf{4 . 4 1}$ \\
\hline $\begin{array}{l}\text { My involvement with the online PBL activity will support me to } \\
\text { learn on my own }\end{array}$ & $\mathbf{4 . 2 2}$ \\
\hline $\begin{array}{l}\text { The group found it easy to identify the learning objectives of the } \\
\text { online PBL activity online }\end{array}$ & $\mathbf{4 . 2 1}$ \\
\hline $\begin{array}{l}\text { The assessment rubric for the online PBL activity assisted to solve } \\
\text { the geography problem successfully }\end{array}$ & $\mathbf{4 . 0 8}$ \\
\hline
\end{tabular}




\begin{tabular}{|l|c|}
$\begin{array}{l}\text { The geography themes used during online PBL were very } \\
\text { interesting }\end{array}$ & $\mathbf{3 . 9 8}$ \\
\hline $\begin{array}{l}\text { The group found it easy to do research about the set learning } \\
\text { objectives }\end{array}$ & $\mathbf{3 . 7 6}$ \\
\hline
\end{tabular}

\section{Geography Student Teacher Perceptions of the Different Role-players in an Online PBL Environment}

Table 6 depicts and compares the geography students' perceptions of the different role-players in the online PBL activities, namely the online tutor, the online group leader and the online group members. The feedback from the respondents with regard to the conduct of the online tutor during PBL tutorial sessions was very positive, with high mean scores of 4.71 and 4.62 regarding tutor feedback and guidance (see Table 6). From the open-ended questions, very positive feedback was received from almost all of the participants, for example: 'We received continuous feedback and guidance as we work from the lecturer' (72, female) and '...he could help us when we are on the wrong track much quicker and contributed to a much better end report, which was not possible in face-to-face environments... and the fact that we all knew the tutor can see who does what' (11, female). The researchers agree with Schmidt et al. (2009) that the tutor, or online tutor, is not a passive observer; he or she must be active and directive about the learning process to assure that the group stays on target and makes reasonable choices on what issues to study. Duncan (2009) points out that the online tutor must provide greater initial scaffolding of students' collaborative working environments (Google Docs in this instance), as they are new to this form of learning. The importance of the online tutor is highlighted by the study of Choo et al. (2011), which investigated the impact of scaffolds on student learning as perceived by students. In their study, it was found that, out of the various types of learning supports provided in a PBL environment, students generally viewed tutor interventions and collaborative small group learning as the most important scaffolds for their learning. This information strongly concurs with an acceptable teaching presence (according to Morueta et al. 2016) in the CoI (see Teaching presences in Table 2), also confirmed by a response from the open-ended questions: 
'...the management of the online activity by the tutor was excellent' (Respondent 53, male).

During the implementation of PBL in the geography modules, it was evident that the online group leaders of most of the groups performed this task effectively. Most of the respondents were of the opinion that the group leaders treated the group members with respect, performed their duties effectively and involved the group members in meaningful group discussions (Table 6). With regard to the statement in the questionnaire, 'The group leader effectively involved all members of the group online to participate in the completion of the online PBL activity', the mean was 4.05.

All the group members in the PBL environment had to collaborate online in order to produce viable solutions to the stated geography problems presented. It is enlightening that the respondents pointed out that the group members displayed respect and understanding for one another's opinions. The item 'Group members respected each other's opinions' (mean $=4.17$ ) received the highest rating, followed by the item 'The group members knew what was being expected of them in the completion of the online PBL activity' (mean = 4.11). From the open questions, many positive comments were received regarding the effective online collaborative support from the technology and how this method also encouraged the group members to work continuously and effectively: 'It forces you to improve your self-discipline, to want to work effectively together, and to make valuable contributions to get the approval of members' (Respondent 23, female).

The item 'Group members critically assessed fellow group members' contributions' (mean $=3.83$ ) received the lowest rating. But if taken into consideration that an acceptable perception of social presence online (according to the CoI framework) is a mean score of 3.98, the group members' involvement is still deemed to be adequate (see Table 2). In fact, the evaluation of the social presence of this PBL activity was higher, with a mean of 4.13. It is necessary to highlight that for most of the respondents, this was their first encounter with online PBL. It is important that online tutors should guide, scaffold and facilitate these students to assess fellow group members' contributions critically (Choo et al. 2011). In this regard, Google Docs assisted in the monitoring of the students' contributions on a daily basis and provided a history of the activities of individuals. As such, the group members were more serious about collaborating and willing to follow the group conventions and practices. This concurs with findings from Suwantarathip and Wichadee (2014). 
Table 6: Geography students teachers' perceptions of the different roleplayers in the online PBL process

\begin{tabular}{|c|c|}
\hline Role-players & Mean \\
\hline \multicolumn{2}{|l|}{ Online geography tutor } \\
\hline $\begin{array}{l}\text { The online tutor provided the groups with regular feedback about } \\
\text { solving the geography problem }\end{array}$ & 4.71 \\
\hline $\begin{array}{l}\text { The online tutor was available to guide students in solving the } \\
\text { geography problem }\end{array}$ & 4.62 \\
\hline \multicolumn{2}{|l|}{ Online group leader } \\
\hline The group leader managed the online PBL process well & 4.18 \\
\hline $\begin{array}{l}\text { The group leader effectively involved all members of the group } \\
\text { online to participate in the completion of the online PBL activity }\end{array}$ & 4.05 \\
\hline \multicolumn{2}{|l|}{ Online group members } \\
\hline The group members respected one another's opinions & 4.17 \\
\hline $\begin{array}{l}\text { The group members knew what was being expected of them in the } \\
\text { completion of the online PBL activity }\end{array}$ & 4.11 \\
\hline $\begin{array}{l}\text { The online PBL activity assisted me to develop positive } \\
\text { interpersonal relationships with the group members }\end{array}$ & 3.79 \\
\hline The group members collaborated well online to solve the problem & 3.92 \\
\hline All the group members did their part in solving the online problem & 3.91 \\
\hline $\begin{array}{l}\text { The group members critically assessed fellow group members' } \\
\text { contributions }\end{array}$ & 3.83 \\
\hline $\begin{array}{l}\text { The group members influenced one another negatively about the } \\
\text { online PBL activity }\end{array}$ & 2.07 \\
\hline
\end{tabular}




\section{Conclusions and Recommendations}

The results from this study show that geography student teachers in a South African context perceive online PBL to be an effective teaching and learning strategy. Online PBL appears to have offered a more student-driven approach to learning, which better facilitated skills such as searching for content, retrieving information, online collaborative learning and online discussions to share ideas and information in order to solve the stated geography problems. Online PBL enhances accessibility, flexibility and convenience for geography student teachers in working any place and at any time. For the effective implementation of online PBL, it is necessary for all the role-players to do their part in a collaborative learning environment. In this study, geography student teachers highlighted the important role of the online tutor to guide, scaffold and support them in solving problems online. They indicated that the online group leaders and group members had collaborated in an effective and meaningful way in solving the problems online. Taking into consideration that it had been their first encounter with online PBL for most of the student teachers, it would have taken them time to develop the necessary problemsolving skills. However, most of the student teachers were of the opinion that the online PBL had motivated them to learn.

When teaching and learning take place online, it is crucial that these adhere to good online design and implementation principles. According to the CoI framework principles of determining the effectiveness of the three interdependent elements, namely the teaching, social and cognitive presences, it is found that this online PBL activity was well above the norm. As PBL is a higher-order learning activity (according to Bloom's taxonomy), it is important to ensure, when it is done online, that effective, continuous collaboration is possible. This study proved to have an excellent social presence that made a higher level of cognitive presence possible. It seems from the findings of this study that it is more effective to conduct PBL online than in contact environments. In this regard, it must be emphasised that the use of Google Docs, as an online collaborative application managed within the LMS of the university, ensured that all the role-players contributed to solving the stated geography problems.

The findings of the study can be used as feedback to geography lecturers in the implementation of online PBL in geography modules. It is also suggested that further studies might explore diverse online PBL modules in 
different subject areas or disciplines, as well as at different levels of learning, in order to determine students' perceptions in different contexts. It is also necessary that future research explore extra supportive technologies for online PBL. It is recommended to consider using online PBL for part of a module in the various academic years in a programme because of the workload of lecturers and student teachers.

To improve the online PBL process, the geography student teachers recommended smaller online PBL groups and the implementation of a chatroom platform on the LMS. They highlighted the most meaningful aspects of online PBL to be the collaboration online, which established a sound social presence, and the continuous support and commentary of the online tutor.

\section{References}

Aldridge, J.M., B.J. Frazer \& M.P. Sebela 2004. Using Teacher Action Research to Promote Constructivist Learning Environments in South Africa. South African Journal of Education 24,4: 245 - 253.

Arbaugh, J.B., M. Cleveland-Innes, S.R. Diaz, D.R. Garrison, P. Ice, J.C.

Richardson \& K.P. Swan 2008. Developing a Community of Inquiry Instrument: Testing a Measure of the Community of Inquiry Framework Using a Multi-institutional Sample. The Internet and Higher Education 11,3/4: 133 - 136. https://doi.org/10.1016/j.iheduc.2008.06.003

Borhan, M.T. 2014. Problem-based Learning (PBL) in Teacher Education: A

Review of the Effect of PBL on Pre-service Teachers' Knowledge and

Skills. European Journal of Educational Sciences 1,1: 76 - 87. https://doi.org/10.19044/ejes.v1no1a9

Caesar, M.I.M., R. Jawawi, R. Matzin, M. Shahrill, J.H. Jaidan \& L. Mundia 2016. The Benefits of Adopting a Problem-based Learning Approach on Students' Learning Developments in Secondary Geography Lessons. International Education Studies 9,2: 51 - 65.

https://doi.org/10.5539/ies.v9n2p51

Chernobilsky, E., A. Nagarajan \& C.E. Hmelo-Silver 2005. Problem-based Learning Online: Multiple Perspectives on Collaborative Knowledge Construction. Proceeding of the 2005 Conference on Computer Support for Collaborative Learning. Taipei, Taiwan — May 30 - June 4, 2005. https://doi.org/10.3115/1149293.1149301 
Choo, S.S.Y., J.I. Rotgans, E.H.J. Yew \& H.G. Schmidt 2011. Effect of Worksheet Scaffolds on Student Learning in Problem-based Learning. Advances in Health Sciences Education: Theory and Practice 16,4: 517 528. https://doi.org/10.1007/s10459-011-9288-1

Creswell, J. 2009. Research Design: Qualitative, Quantitative, and Mixed Methods Approaches. $3^{\text {rd }}$ Edition. Thousand Oaks, CA: SAGE.

Creswell, J.W. \& V.L. Plano Clark 2007. Designing and Conducting Mixed Methods Research. California: SAGE.

Dean, C. 1999. Problem-based Learning in Teacher Education. Paper presented at the American Education Research Association Annual Meeting. Montreal.

Dennis, J.K. 2003. Problem-based Learning in Online vs. Face-to-Face Environments. Education for Health 16, 2:198 - 209. Available at: https://doi.org/10.1080/1357628031000116907 (Accessed on 23 June 2018).

De Vos, A.S., H. Strydom, C.B. Fouché \& C.S.L. Delport 2012. Research at Grassroots: For the Social Sciences and Human Service Professions. $4^{\text {th }}$ Edition. Pretoria: Van Schaik.

De Wever, B., H. van Keer, T. Schellens \& M. Valcke 2010. Roles as a Structuring Tool in Online Discussion Groups: The Differential Impact of Different Roles on Social Knowledge Construction. Computers in Human Behavior 26,4: 516-523. https://doi.org/10.1016/j.chb.2009.08.008

Dolmans, D.H.J.M., I.H.A.P. Wolfhagen, C.P.M. van der Vleuten \& W.H.F.W. Wijnen 2001. Solving Problems with Group Work in Problembased Learning: Hold on to the Philosophy. Medical Education 35, 9: 884 - 889. https://doi.org/10.1046/j.1365-2923.2001.00915.x

Duncan, M.J. 2009. The Student Experience of Online Problem-based Learning in Sport and Exercise Science. Practice and Evidence of Scholarship of Teaching and Learning in Higher Education 4,2: 95 - 115. Ellaway, R.H., T. Poulton \& T. Jivram 2015. Decision PBL: A 4-year

Retrospective Case Study of the Use of Virtual Patients in Problem-based Learning. Medical Teacher 37,10: 926-34. Available at:

https://doi.org/10.3109/0142159X.2014.970627. (Accessed on 5 May 2018).

Garrison, D.R., T. Anderson \& W. Archer 2000. Critical Inquiry in a Textbased Environment: Computer Conferencing in Higher Education. The Internet and Higher Education 2,2/3: 87 - 105. 
Gergen, K.J. 1995. Social Construction and the Educational Process. In Steffe, L.P. \& J. Gale (eds.): Constructivism in Education. Hillsdale, NJ: Lawrence Erlbaum Associates.

Glicken, M.D. 2003. Social Research: A Simple Guide. Boston: Pearson.

Glover, I. 2014. Problem-based Learning: An Approach to Teaching and Learning. Technology Enhanced Learning at SHU. Available at: https://blogs.shu.ac.uk/shutel/2014/10/06/problem-based-learning-anapproach-to-teaching-and-

learning/?doing_wp_cron=1530025232.9155910015106201171875

(Accessed on 6 June 2018).

Golightly, A. 2018. The Influence of an Integrated PBL Format on Geography

Students' Perceptions of their Self-directedness in Learning. Journal of

Geography in Higher Education 42,3: 460 - 478.

https://doi.org/10.1080/03098265.2018.1463974

Golightly, A. \& O.A. Muniz 2013. Are South African Geography Education

Students ready for Problem-based Learning? Journal of Geography in

Higher Education 37,3: 432 - 455.

https://doi.org/10.1080/03098265.2013.794332

Golightly, A. \& L.M. Guglielmino 2015. Geography Students' and Student

Tutors' Perceptions of their Self-directedness in Learning in an Integrated

PBL Model: An Exploratory Study. International Journal of Self-

Directed Learning 12,2: 63 - 81.

https://doi.org/10.1016/j.sbspro.2009.01.501

Günbatar, M.S. \& H. Çavuş 2011. Web tabanlı probleme dayalı öğrenmeye ilişkin öğrenci tutumları. Journal of Faculty of Educational Sciences 44,2: $119-140$.

Gürsul, F. \& H. Keser 2009. The Effects of Online and Face-to-Face Problembased Learning Environments in Mathematics Education on Students' Academic Achievement. Procedia - Social and Behavioral Sciences 1,1: 2817 - 2824.

Hamid, S., J. Waycott, S. Kurnia \& S. Chang 2015. Understanding Students'

Perceptions of the Benefits of Online Social Networking Use for Teaching and Learning. The Internet and Higher Education 26:1 - 9.

Hazwanie, H., W.K. David, H.M. Chong, D. Pran Kishore, P.S. Wong, M.S. Lee, M.K. Maharajan, E.L. Lee \& H.Z. Baloch 2017. Students' Perceptions of Live Online Virtual e-Problem-based Learning (LOVEPBL) using Google Hangouts. Education in Medicine Journal 9,4: 31 - 
39. Available at https://doi.org/10.21315/eimj2017.9.4.4 (Accessed on 20 March 2018).

Kivela, J. \& R.J. Kivela 2005. Student Perceptions of an Embedded Problembased Learning Instructional Approach in a Hospitality Undergraduate Program. International Journal of Hospitality Management 24:437 - 464. https://doi.org/10.1016/j.ijhm.2004.09.007

Kolossov, V., J. van der Schee \& J. Lidstone 2016. International Charter on Geographical Education. International Geographical Union Commission on Geographical Education. August. Available at http://www.igu-cge.org Accessed on 13 May 2018.)

Kwan, T. 2008. Evaluation of the Learning Experiences of Using Different Modes of Problem-based Learning in an Initial Teacher Education Programme. Asia-Pacific Journal of Teacher Education 36, 4:323 - 343. https://doi.org/10.1080/13598660802375933

Lam, D.O.B. 2009. Impact of Problem-based Learning on Social Work Students: Growth and Limits. British Journal of Social Work 39,8: 14991517. https://doi.org/10.1093/bjsw/bcn073

Lee, S.M. 2014. The Relationships between Higher Order Thinking Skills, Cognitive Density, and Social Presence in Online Learning. The Internet and Higher Education 21: 41 - 52.

https://doi.org/10.1016/j.iheduc.2013.12.002

Leedy, P.D. \& J.E. Ormrod 2001. Practical Research: Planning and Design $7^{\text {th }}$ Edition. New Jersey: Merrill Prentice Hall.

Morueta, R.T., P.M. López, A.H. Gómez \& V.W. Harris 2016. Exploring Social and Cognitive Presences in Community of Inquiry to Perform Higher Cognitive Tasks. Internet and Higher Education 31,10: 122 - 131. https://doi.org/10.1016/j.iheduc.2016.07.004

Nelson, E.T. 2007. Effects of Online Problem-based Learning on Teachers' Technology Perceptions and Planning. Doctor of Philosophy. Capella University.

Ng, M.L., S. Bridges, S.P. Law \& T. Whitehill 2013. Designing, Implementing and Evaluating an Online Problem-based Learning (PBL) Environment A Pilot Study. Clinical Linguistics \& Phonetics 28,1-2: 117 - 130. https://doi.org/10.3109/02699206.2013.807879

Ó Broin, D. \& D. Raftery 2011. Using Google Docs to Support Project-based Learning. AISHE-J 3,1:00035.1-00035.11

Park, S.H. \& P.A. Ertmer 2008. Examining Barriers in Technology-enhanced 
Problem-based Learning: Using a Performance Support Systems Approach. British Journal of Educational Technology 39,4: 631 - 643. https://doi.org/10.1111/j.1467-8535.2008.00858.x

Rapchak, M.E. 2017. Creating a Community of Inquiry in Online Library

Instruction. Journal of Library \& Information Services in Distance Learning 11,1-2: 59 - 67.

Reynolds, M. 2016. Your Guide to Collaborative Document Editing with Google Docs. Spinweb. Available at:

https://www.mojomedialabs.com/blog/your-guide-to-collaborativedocument-editing-with-google-docs; and https://blog.spinweb.net/howto-collaborate-with-google-docs (Accessed on 10 March 2018).

Richardson, J.C. \& P. Ice 2010. Investigating Students' Level of Critical Thinking across Instructional Strategies in Online Discussions. Internet and Higher Education 13: 52 - 59.

https://doi.org/10.1016/j.iheduc.2009.10.009

Ruey, S. 2010. A Case Study of Constructivist Instructional Strategies for Adult Online Teaching. British Journal of Educational Technology 41,5: 467-535.

https://doi.org/10.1111/j.1467-8535.2009.00965.x

Ryan, G., S. Taylor, C. Graham, J. Woulfe \& C. Seeta 2009. Implementing 'low tech' Online PBL: A Case-study in Rural Pharmacy Education. Synergy 29: 2 - 11.

Tichon J.G. 2002. Problem-based Learning: A Case Study in Providing eHealth Education Using the Internet. Journal of Telemedicine and Telecare 8,S3: 66 - 68. Available at:

https://doi.org/10.1258/13576330260440907. (Accessed on 28 April 2018.)

Tick, A. 2007. Application of Problem-based Learning in Classroom Activities and Multimedia. Paper presented at the $5^{\text {th }}$ Slovakian Hungarian Joint Symposium on Applied Machine Intelligence and Informatics, Poprad, Slovakia.

Tsai, C.W. \& Y.C. Chiang 2013. Research Trends in Problem-based Learning (PBL) Research in e-Learning and Online Education Environments: A Review of Publications in SSCI-indexed Journals from 2004 to 2012. British Journal of Educational Technology 44,6: E185 - E190. https://doi.org/10.1111/bjet.12038

Savin-Baden, M. 2007. A Practical Guide to Problem-based Learning Online. 
London: Routledge. https://doi.org/10.4324/9780203938140

Schmidt, H.G., H.T. van der Molen, W.W.R. TeWinkel \& W.H.F.W. Wijnen 2009. Constructivist, Problem-based Learning does Work: A Metaanalysis of Curricula Comparisons Involving a Single Medical School. Educational Psychologist 44,4: 227 - 249.

https://doi.org/10.1080/00461520903213592

Schreiber, L.M. \& B.E. Valle 2013. Social Constructivist Teaching Strategies in the Small Group Classroom. SAGE 44,4: 395 - 411.

https://doi.org/10.1177/1046496413488422

South Africa. Department of Basic Education 2011. Curriculum and Assessment Policy Statements. Geography. Pretoria: Government Printing Works.

Strøms $\varnothing$, H.I., P. Grøttum \& K.H. Lycke 2004. Changes in Student Approaches to Learning with the Introduction of Computer-supported Problem-based learning. Medical Education 38: 390-398. https://doi.org/10.1046/j.13652923.2004.01786.x

Sulaiman, F. 2011. The Effectiveness of Problem-Based Learning (PBL) Online on Students' Creative and Critical Thinking in Physics at Tertiary Level in Malaysia. Doctor of Philosophy. University of Waikato, Hamilton, New Zealand. https://hdl.handle.net/10289/4963

Suwantarathip, O. \& S. Wichadee 2014. The Effects of Collaborative Writing Activity using Google Docs on Students' Writing Abilities. The Turkish Online Journal of Educational Technology 13,2: 148 - 156.

Van der Westhuizen, C.P. 2017. Optimizing the CoI Principles of Online Problem-based Blended Learning Environments. The Scholarship of Teaching and Learning Conference, $21 \& 22$ September 2017. SoTL: A Vehicle for Critical Reflection on Practice.

Veldman F.J., N.E.I. Mokhele, M.A. de Wet \& W.A.J. Bouwer 2008. Can Engineering Education in South Africa afford to Avoid Problem-Based Learning as Didactic Approach? European Journal of Engineering Education 33,5-6: 551 - 559.

Woods, D.R. 1994. Problem-Based Learning: How to Gain the Most from $P B L$. Waterdown: Donald R. Woods Publishers.

Xie, Y. \& S. Kim 2012. A Design Model of Harnessing Wiki for Collaborative Problem-based Instruction in Higher Education. In Seo, K.K., D.A. Pellegrino \& C. Engelhard (eds.): Designing Problem-driven Instruction Using Online Social Media. Charlotte, NC: Information Age Publishing. 
Zhu, C. 2012. Student Satisfaction, Performance, and Knowledge Construction in Online Collaborative Learning. Educational Technology \& Society 15,1: $127-136$.

Aubrey Golightly

Geography and Environmental Education School of Mathematics, Science and Technology Education Faculty of Education Potchefstroom Campus North-West University Aubrey.Golightly@nwu.ac.za

Christo van der Westhuizen Geography and Environmental Education School of Mathematics, Sciences and Technology for Education Faculty of Education Potchefstroom Campus North-West University VanDerWesthuizen@nwu.ac.za 